\title{
The Egyptian Museum in Cairo (EMC) Past and Present
}

Rania Mostafa Eshaq Abdalla, Ali Omar Abdallah and Osama Abd El-Wareth Abd El-Megiud

\begin{abstract}
The Egyptian Museum, which is one of the largest museums in the world and the first national museum of antiquities in the Middle East, had a long history of construction. Its story begins when Muhammad Ali Pasha noticed the absurdity that occurs to antiquities, especially by foreigners, whether visitors or residents in Egypt, and their acquisition and smuggling and hence, he issued several orders to reduce this. This paper introduces the Egyptian Museum through the western inspiration. In addition, it presents the history of the Egyptian Museum in Cairo display starting from the background history and the beginning at Bulaq museum till present. It also discusses the architectural description of the museum. Moreover, it also discusses the Egyptian museum management and the structure of the museum's exhibitions. This paper lists the museum renovations and developments along 118 years. It also discusses the educational role of the museum. And then, it presents an overview about the future vision of the three great museums of Egypt. It ends by the current European project in the EMC, and some recommendations towards the future of the Egyptian Museum in Cairo.
\end{abstract}

\section{Keywords:}

antiquities, acquisition, history, architecture, display, renovation.

\section{Introduction}

The EMC houses the world's largest collection of antiquities from Pharaonic Egypt. The museum database records not less than one hundred and sixty thousand pieces currently, which fill the galleries, and storage facilities. The Egyptian government decided to build the EMC in the center of Cairo to be the first building built intentionally to function as a museum. The work started in 1897, and the museum was opened on the $15^{\text {th }}$ of November 1902 . The building was designed by the French architect "Marcel Dourgnon", and it comprises more than 100 display halls distributed on two floors. There is also a big wide basement used to store. Another storage area is located in a part of the third floor. Along with some stone objects, in the garden of the museum are displayed the sarcophagus, and bronze statue of 'Auguste Mariette' in its western part (a French Egyptologist who came to Egypt in 1881 and got involved in excavations), and his statue is surrounded by other busts of distinguished Egyptian, and foreign Egyptologists ${ }^{1}$.

The current display situation of the Egyptian museum, which is one of the most important museums for ancient Egyptian artifacts, still keeps its ancient identity as a place for preserving artifacts. The first display of the museum's collection was considered an outstanding display compared with other museums at the same time; the same concept of the old display still exists till these days. The objects on the ground floor are arranged in a chronological order. The museum collection is classified by chronology or in themes such as the mummies (on the museum plan; the ground floor is the $1^{\text {st }}$ and the first floor is the $\left.2^{\text {nd }}\right)$, which are the remarkable series of Pharaohs which were found in Thebes in the later years of the $19^{\text {th }}$ century, and their acquisition gives this museum a unique position among all the world's museums. The objects are of storytelling kind to give the visitor an idea of the use to which they were set in ancient times. The Egyptian Museum is the only museum in the world that is so piled and heaped with antiquities that it became a storehouse, and when Maspero was asked about the reason for that, he said: "The Egyptian Museum is an image of the cemetery or the Pharaonic temple, where the artist was exploiting every part to place a painting or hieroglyphic inscription. In fact, the modern Egyptian house at that time used to put up paintings and pictures so that every part on the wall is exploited. That is, the museum is a picture of the present and ancient Egyptians"2.

1 Mohamed Saleh and Hourig Sourouzian, Official Catalogue of the Egyptian Museum, Cairo (1987).

2 Zahi Hawass, “Antiquities and Secrets of the Egyptian Museum: A Century of Time”, Issues and opinions, December 7, 2002, https://web.archive.org/ web/20040109165300/http://www.ahram.org.eg:80/archive/2002/12/7/OPIN12.HTM 


\section{The Egyptian museum through the western inspiration}

In the half-century between 1858 and 1908, Europeans played key roles in the founding of the 'Egyptian Antiquities Service' and four historical museums: the Egyptian Museum (for the pharaonic period), the Graeco-Roman Museum, the Coptic Museum, and the Museum of Arab (now Islamic) Art. A century later, in 1902, the facade of Cairo's Egyptian Museum and the garden monument to its founder, Auguste Mariette, were ornamented and inscribed with names of heroes of the European Egyptology, since the time of Napoleon, in an honoring commemoration of them ${ }^{3}$.

In the second half of the $19^{\text {th}}$ Century, a systematic understanding of Egyptian antiquity was introduced through the emeroing discipline of Egyptology. The chronological framework introduced by archaeological studies replaced many of the earlier concepts about Eoyptian history based on classical studies of Greek and Roman art history. The earliest principles of Eoyptian archaeology have had a direct and lasting impact on Egyptian museum arrangements. Throughout the 19th Century, Pharaonic culture became synonymous with Egypt influenced and affected by a Western- Orientalist perspective in literature, painting, photography, and exhibition. From this perspective and with the European aesthetic, the first major Egyptian museums established an exhibitioner order that reflected Western ideologies by separating Egyptian history within the urban fabric of Egypt itself. In the original formulation, the Museum of Egyptian Antiquities in the heart of Cairo came to represent an indigenous Egyptian culture and the other three collections were presented and viewed as ethnic deviations. Of the Pharaonic, classical, Byzantine, and Islamic civilizations, only the former would serve as a synonym for Egyptian. There would be some overlap between Pharaonic and classical antiquities in the museum's early collection, but the Coptic and Islamic traditions remained isolated ${ }^{4}$.

\section{Egyptian museum's history}

The Egyptian Museum Cairo has been around for more than one hundred years, and is one of the most famous landmarks in the showcase its cultural heritage and attract visitors from all over the world

Early in Egypt's history, when Champollion came to Egypt in 1828, willing to excavate and study antiquities, he was received by Muhammad Ali Pasha who knew of his intentions and saw what Egypt could benefit from him. Muhammad Ali was one of those who appreciate men like Champollion, so he gave Champollion the necessary protection and facilities, and Champollion went from one site to another, discovered fifty sites in nineteen months, and documented the results of this journey in six large volumes under the title "The Magnificence of Egypt and Nubia". In 1835, Mohamed Ali issued a decree to build a house for Egyptian antiquities in the house of al-Daffrdar near the Azbakiya pond and banned any further excavation of antiquities except with permission and prevented their exit from Egypt as he ordered the transfer of the discovered antiquities to the Azbakiya Museum. However, the Azbakiya Museum did not survive and the antiquities in it were transferred to the Citadel in 1850 and became open for private visits only, and in 1854 when the Austrian Crown Prince Maximilian visited Egypt, he visited the Citadel Museum, he was very impressed, and he expressed his admiration of the collection to Abbas I, the governor of Egypt at the time, showing eagerness to obtain some artifacts from this collection ${ }^{6}$.

Auguste Mariette arrived in Egypt in September 1850, Mariette was able to obtain a recommendation from the head of the Monastery of Al-Anba Makar, but he had to wait for fifteen days, and in the meantime, he visited the antiquities of Giza and Saqqara, which he was inspired by. Mariette succeeded in obtaining the building of the river navigation company at the port of Bulaq to save the antiquities he found, using four full rooms for display (See figures 1-2). As soon as he discovered the antiquities of the Queen (Iah-Hotep) Dera Abu el-naga in 1859, Mariette decided that this place had to be expanded and that it had to be converted into a museum. He was able to reach his goal during the reign of Ismail Pasha, who ordered the repair and expansion of the Bulaq stores and its expansion into a museum which was officially opened on 18/10/1863. In 1878 came the flood of the Nile causing serious damage to the Museum of Bulaq, and in an attempt to save the antiquities they were stored until the completion of the restoration and repair of the museum, which cost enormous amounts. The idea of establishing a new museum became urgent because of the dangers surrounding the Museum of Bulaq which was affected by the flood of the Nile in 1878. Therefore, it became a must to transfer the antiquities to Saray Ismail Pasha in Giza (See figure 3). The transferring

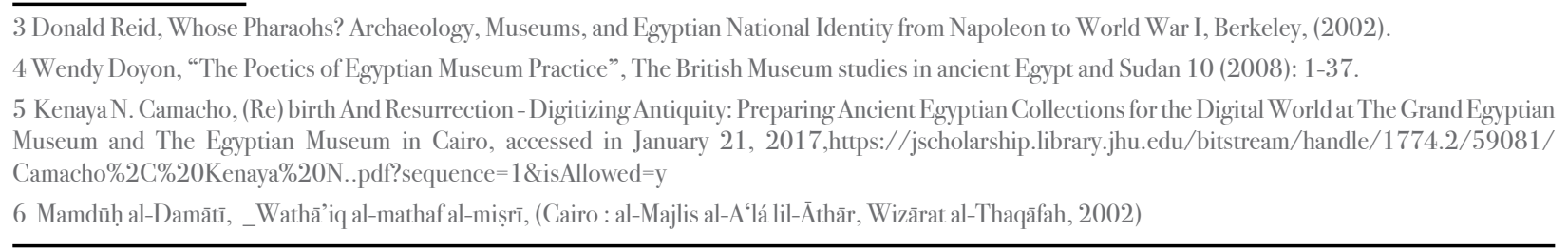

(a) started in 1889 to Saray Ismail Pasha in Giza under the supervision of Grebo director of the Department of Antiquities who succeeded Maspero

The Egyptian government decided on the idea of constructing of a new museum (See figure 4). An international competition for the best design for the construction of the new museum was announced in 1895 , and its location was selected in Ismailia Square (present-day Tahrir Square). Marcel Dornion was selected for his design of the Egyptian museum building among seventy

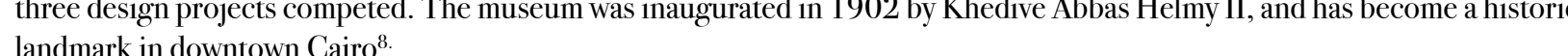

\section{Architectural description of the Egyptian museum}

The Egyptian museum was the first museum in the world to be designed and built as a museum rather than abuilding that has been converted into a museum, and it had followed the latest construction methods applied in that era. The patterns and elements of the architecture is influenced by classical (Greek) art and architecture, and it contains no influences of ancient Egyptian art an

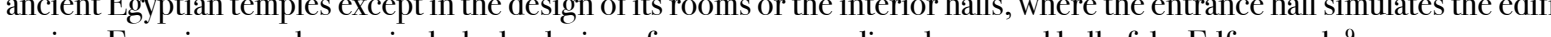
ancient Egyptian temples particularly the design of rooms surrounding the central hall of the Edfu temple ${ }^{9}$.

It is thought that Marcel Dornion, was inspired by the ancient Egyptian artists or engineering when planning the structure of the ancient Egyptian temples and other monument. So, as the ancient Egyptian depicted elements from nature as the papyrus plants, the lotus flower and palm leaves, Marcel Dornion used the same motives as well to create the original context of the vet The ero display in the Egyptian museum. The foundation stone of the musent

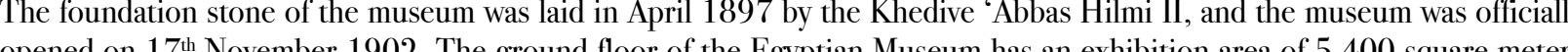
opened on $17^{\text {th }}$ November 1902. The ground floor of the Egyptian Museum has an exhibition area of 5,400 square meters
set aside for the chronological display of Egyptian antiquities. The first floor is dedicated to the display of ancient objects of Egyptian civilization, arranged by themes, and contains complete archaeological collections, all in an area covering 3,500 square meters. The second floor is devoted to collections of sarcophagi from different eras and is reserved for scholars, althoug a plan is being developed to open it to the general public. Access to the entire area of the museum, the midsection of the ground floor is approximately 45x16 square meters and sits low on a number of steps leading down from the ground floor. The display in this section has been made to resemble ancient Egyptian temples consisting of large portals and statues, such as those of Amenhotep III and his wife Tiy. This part of the museum contains a gabled ceiling covered by glass panels, allowing for some of the sof tight needed to erate the awe-inspiring atmosphere of ancient Egyplan temples. Thisis the centre of the museum, wit galleries and rooms on al sides; beginning to the left of the entrance, the round continues until it reaches the entrance again in a historical sequence beginning with the pre and early dynastic periods and continuing to the Old, Middle and New Kingdoms. and finally the late period and some hightights of small collection of Graceo-koman period"

Most of the upper floor rooms overlook those below to provide visitors with detailed view of the upper parts of the huge statues, thus vitizing the display. Below the ground lloor there is the basement, the museum's main storage room for majo

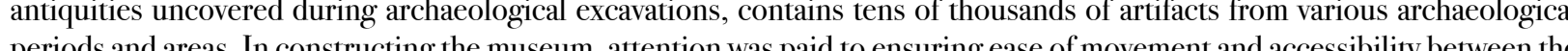
various sections In eneral the atipuries are diphyed in the musem in However, one section may contain different artifacts arranged by type rather than period These artifacts are displayed in wooden showcases labeled with descriptions of each object and detajs of its period, orioin and the material used in its manuf Some of the large heavy objects are not placed in wooden showcases, but still they are also labeled with descriptions ${ }^{11}$ In the garden adjacent to the museum building, a memorial to famous Egyptologists of the world is located (See figure 5) features a monument to Auguste Mariette, surrounded by 24 busts of the following famous Eoyptologists at the history of the Egyptian museum ${ }^{12}$

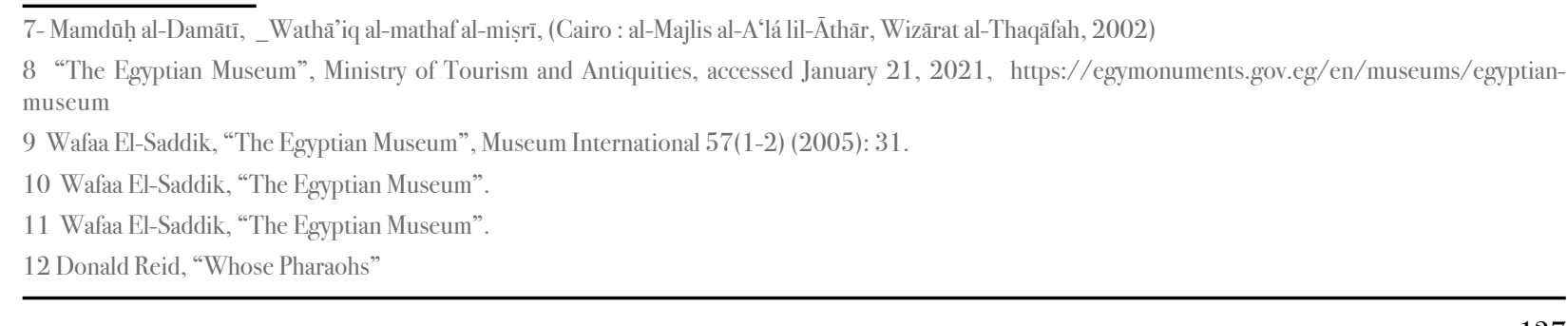




\section{Egyptian museum management and the structure of the museum's exhibitions}

The Egyptian curatorial tradition is absolutely crucial to a broader understanding of the arrangement of the personnel that governs the museum's administration. In the principal museum tradition, the work of the curators comprises two roles referred to as: committee work and public relations. The work of committees includes major projects of collections management, conservation, study, and display, as well as routine tasks such as movement of objects, photography, labels revision, exhibition
preparation, lighting, and furniture repair. Committees are generally composed of three or more curators as well as the preparation, lighting, and furniture repair. Committees are generally composed of three or more curators as well as the
technicians, carpenters, object handlers, security personnel, and specialists required for a particular project. The Egyptian Museum atracts huge numbers of visitors annually, double the average admission to all other major antiquities museums in Egypt combined ${ }^{13}$.

In general, the people who work in the Egyptian museums still need guidance to move to the international technicalities through a lot of training to equal international museums standards ${ }^{14}$

All forms of archaeological representation, which is the production of meaning through a visual language to communicate with the past, rely on the repetition of certain themes to establish social clarity. Museums are one of the most important media in archaeology, adding a material dimension to the visualization of history. By observing patterns in the arrangement and composition of archaeological displays, museum exhibition can be read as a visual narrative negotiating ideological links to the past The structure of the exhibition is based on distinctions between the main object categories (monumental architecture, relief, statuary, and stelae) and minor object categories (ceramics, lithics, textiles, jewelry, figures, ostraca, papyri, and coins), which reflect disciplinary differences between the history of art and material culture. Material sub-categories include ceramic, glass, ivory, bone, metal, wood, stone, etc. Centerpieces on display usually include highly recognizable or iconic items such as decorated pre-dynastic pottery, Pharaonic offering tables, Coptic scripture, and Islamic lanterns

Mummification is the only ubiquitously thematic archaeological exhibit and as a theme it surpasses all other historical contexts. Displays associated with death and burial in ancient Egypt are always set apart from a museum's main exhibition with little chronological attention. Writing and papyri is another common theme, but in general thematic exhibits are still far less common than classification exhibitions. Common representations of ancient Egypt focus on divinity and kingship, writing, mummification, agriculture, and military themes. Ancient Egyptian representations have long been used to support the political agendas of Western nations and to provide Western cultures and societies with a cultural and exotic counterpart ${ }^{16}$.

It is noteworthy that the Egyptian Museum display has created the context to the collection of Tutankhamen. Although it is an old display but it had a contextual display concerning the historical context and the story of the discovery, so, the gallery begins with the two guardians the same way that they were found in the tomb; the old photos of the discovery moments were combined with the display showing the collection also the same way as it was found. This display contextualized the collection inside the tomb attached to their original location. The display of Hutankhamen is considered unique as the international museums were not explicitly developed this time. Also, for the showcases, they were suitable and accessible for the visitors regarding the space of the visit and the visual level.

There are also some collections displayed together and played their role in the context of display such as: 'Yuya and Thuya' collection in the western gallery on the first floor, and 'Maiherpri' which is now in room P1 7 -under renovation- $\left(18^{\text {th }}\right.$ Dynasty, Biban el-Muluk, tomb K V36, Theses. west, Valley oKings, Laxor/ ENG database). Additionally, here were two collections which are now in the NMLC, hie firs for 'Sennedjen' Collecion which was in oom P17, (New kingdom, Deir el-Madina, tomb TT1, Thebes: west; Luxor/ EMC database), the second for 'Hemaka' (1" dynasty/Saqqara/ EMC database). Also, some of

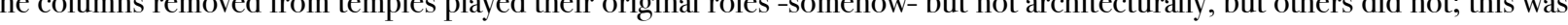
according to the place of displaying them inside the museum. The floor of the palace of Akhenaten also presented a dual role in creating the context, as the part displayed on the ground floor re-created the function of it, but the parts which were cut and hanged on different walls in the museum lost their main function as they were originally part of a floor.

13 Doyon, "The Poetics", $1-37$

(2005):7.

15 Doyon, "The Poetics", 1-37.

\section{Egyptian museum renovations}

The Egyptian Museum had several renovations and developments through its history. At the end of 1977, the Egyptian museum projects began. The floor of the ground level was in a poor condition and restoration processes failed to keep it in good appearance; they began by renewing it. With the administrative changes in 1981again began covering the floor of the museum faced more problems:

- There was not space to allow an average of $4000-5000$ visitors to move and enjoy being in the museum daily

- Air-circulation in the museum in the hot and humid months of the summer is lacking, although the museum was provided in the last years with fans to help having some air-movement (and not circulation).

- Security: Physical security by guards served to attain the museum security. This system is no more proper.

- Illumination: At the museum, we have some parts well and properly lighted naturally. Other galleries in the museum are over lighted or poorly lighted.

- Pollution and noise.

Curatorial problems: Trained curators are being missed because of retirements or attractive salaries and working conditions in universities, private sectors, and tourism.

The museum had undergone several renovations from 1975 to early 1999. In 1996, the Egyptian museum got provided with a new security system and air-conditions in some of the rooms, new magazines and improved the museum displays.

Documentation: Special database was set up for the museum, and accurate documentation of objects is being implemented ${ }^{18}$. The documentation and collections management system at the museum is centered on the new Egyptian Museum Collection Management Database, which is supplemented and backed up by a fully manual system. The EMC database stores full and accurate object information for all of the artifacts in the museum, along with all collections management data ${ }^{19}$.

The Egyptian Museum Database Project initially began in 2005. In its first iteration, the new database was established using File-maker Pro, to replace an older database at hie museum. The new database was meant to record "basic object informatio and collections management data, such as object location and object movement". The volunteer database team at the time had no access to the museum's register books and could only input data from the museum's published catalogues into File-make Pro. Eventually in 2009, the EMC database was migrated to the collections management system $\mathrm{KE} \mathrm{Emu}^{20}$. Restoration: A small unit of restoration works in a very satisfactory way. We received the help of the Romish- Germannish museum in Mainz for the restoration of the difficult copper statues of Pepi 1 and his son ${ }^{21}$.

On 9 December 2002, Egypt celebrated a great occasion (The centennial of the EMC); it has been a hundred years since the Egyptian Museum was established. An archaeological exhibition was held, and it included newly discovered pieces from al the archaeological areas. It was firstly displayed inside the basement of the tinuseum, and this exhibition was called "Hidde treasures'; and a huge tent was erected on the west side of the museum, in which the ceremony was held, and which witnessed a unique concert attended by seven hundred people from Egypt and countries around the world, who came to celebrate the establishment of the only museum, which was inaugurated in 1902

The archival temporary exhibition was the collection of the archival papers, registers, plans and catalogues that tell the history of the Egyptian museum. The centennial of the ENG was a worldwide celebration where many VIPs attended, ministers an international scholars, artists and actors and headed by the president's wife 'Suzan Mubarak'. And the whole museum wa painted inside out ${ }^{23}$

The year 2003 completely changed the image of the Egyptian Museum, where the main entrance to the museum became a doo

17 Diaa Abou-Ghazi, “The Foyptian museum”, Annales du Service des Antiquites de L'Eoypte, Vol. LXVI (1978): p. 201-202

18 Mohamed Saleh, " "Egyptian Museum Renovations", personal communication with author, November, 2020.

19 Janice Kamrin, The Egyptian Museum Database, Digitizing, and Registrar Training Projects: Update 2012, accessed January 21, (2021), file:///Users/

(2)

21

22 Hawass, "Antiquities".

23 Flham Salah el-Din, personal communication with author, Auoust, 2020 . 
for visitors only, and all sales outlets and cafeterias were removed ${ }^{24}$

Temporary exhibits have rarely been in the museum, but starting in 2008 , it was practically held back again, with only three months or less between each of them. The number of external exhibitions has also increased, allowing museum treasures to be seen far beyond Tahrir Square 25.

\section{The educational role of the Egyptian museum}

The role of modern museums should not be restricted only to such academic/scientific tasks, they should also have a cultural and educational mission, connecting cultural heritage with the surrounding community. In lioht of this, the Foyptian Museum, Educational Center was created, comprising two main units:

1. A school for adults, which operated twice a year (each time for 25 weeks) for the study of history, civilization, and archaeoloogy: 1. Aschool for adults, which operated twice ayear (each time for 25 weeks) for the study of history, civilization, and archaeology; The first round began in January 2002. The idea was originally spawned by the Secretary-General of the SCA, and supervised by Dr. Samia El Mallah and Ms. Elham Salah Eldin.

2. A school and workshop for students of all ages, which was inaugurated on the $18^{\text {th }}$ of January $2002^{26}$.

The museums are overwhelmed with responsibilities of teaching and educating their communities for saving their heritage under any circumstances.

During the $21^{\text {st }}$ century the ministry of culture and antiquities managed a program for renovating the Egyptian museum and built two new museums, a project which started by an Italian fund project in 2000 and then continued by the Egyptians.

\section{The future of the Egyptian museum and the other new Grand museums}

The three principal museums in Egypt that were addressed by the new program are: the Grand Museum of Egypt (GEM) built near the Pyramids, the National Civilization Museum (NMEC) at Fustat, and the existing Egyptian Museum (EMC) in Tahrir Square. The project aims were that every museum has its own character, a distinctive feature that attracts people. The main feature of the new Grand Museum near the pyramids of Giza will be the 5,000 artifacts from the tomb of Tutankhamun but its collections will be extensive. The Civilization Museum in Fustat will depict the entire historical landscape of Egypt and will also house the royal mummies. The Egyptian Museum will display the history of $\operatorname{art}^{27}$. Although the Grand Museum will contain Tutankhamen collection, and the Fustat Museum will contain the mummies; the Egyptian Museum will remain a museum of ancient Egyptian art, and the exhibits will be reduced and transferred to other museums, and the galleries of the museum will be supplied with effects of the highest level to suit the display of the museum and the grandeur of its history ${ }^{2}$.

The author states that the ancient Egyptians themselves appreciated beauty and showed interest in it, so they created $2 \mathrm{D}$ reliefs and 3D models, which represent a non-intentional context to reflect their daily life inspired with their thoughts and philosophy. This is the time for change, and the permanent display of the Egyptian museum has to develop following the development of the scientific research field of archaeology and museums that was produced copiously through the recent years. The Egyptian museum in Cairo has currently a renovation project of the European Union (EU), where the benefit of the context of display is considered based on the international standard

\section{European Union renovation project}

In 2018, the Minister of Antiquities with the Egyptian-European Scientific Committee, have discussed the final proposal of the Egyptian Museum in Cairo (EMC) development project. The development process is carried out with the grant of the European Union and is implemented jointly by the Ministry of Antiquities and the consortium of directors of five European museums with a display of major Egyptian collections. The MoA Committee and the EU Consortium have selected a suite of galleries for redisplay at the entrance of the EMC (Work Package 1), to ensure maximum impact and visibility for the project (See figure 6). The suite comprises:

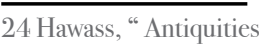

1. The entrance rotunda 'room 48 '

. The gallery 'room 43 ' between the rotunda and the grand atrium.

The Late Period and Ptolemaic galleries to the east of the rotunda 'rooms 49 and 50"29.

There will remain about 5000 objects in the EMC after the current movements to the other museums. The museum should have a new context of display. For example, as for Khufu, the great king of the $4^{\text {th }}$ dynasty and the only statue, it is better to have a new display combined with some objects from the same period and supporting tools highlighting his reign. Moreover, the museum could link the statue to his great monument (the great pyramid) to contextualize it. Also for the collection of 'Meketre', which was divided before 1983 law, between the EMC and the Met, it is better to have a new display in a large room to clarify the important significance of the collection and support the display by digital tools indicating to the other part of the collection in the Met (to make a connection between the collection) to create the context for them as a complete collection to clarify their function and to give the visitor a good vision for the whole collection. Another example is the statues of 'Rehetep and Nefert' from the $4^{\text {th }}$ dynasty; they are displayed in room 42 while the walls of their tomb displayed in room 32 . Displaying the statues with the walls of their tomb in one gallery would help to re-create the context of the tomb as a complete construction. the other part in not be divided because it does not make sense for the visitors to see part of a tomb collection in a gallery and temple from the $5^{\text {th }}$ dynasty; they varied between (Creat columns, blocks, fragments, parts of walls reliefs, and the finest hes for Ptahshepses from quartzite), It would be better for the collection to be gathered in the same gallery and to make a link to their original site in Abusir. Some of the objects, of the King Sahure, were recently transferred from the EMC to the GEM, and it would be better if the GEM could re-construct the context of the king's temple by linking the objects to their original location where the temple was. Even though dividing collections between museums is not accepted, finally we have to deal with the current situation.

\section{Conclusions}

The Ministry of Antiquities has a strategy for the three Grand Museums, GEM, NMEC and EMC which give concept, themes and story for each one of them; also the curators and other professors' teams chose the related collection to each theme and story. Finally, the Egyptian museum decided on 5000 masterpieces to keep for EMC to be displayed according to the new scenario after the renovation. These selected 5000 pieces covered the history from the archaic period to the Graeco-Roman period and would never be moved from the EMC to any other museum. The future vision for the new display of the EMC is still discussing and searching for standard of re-contextualization. 


\section{Figures}
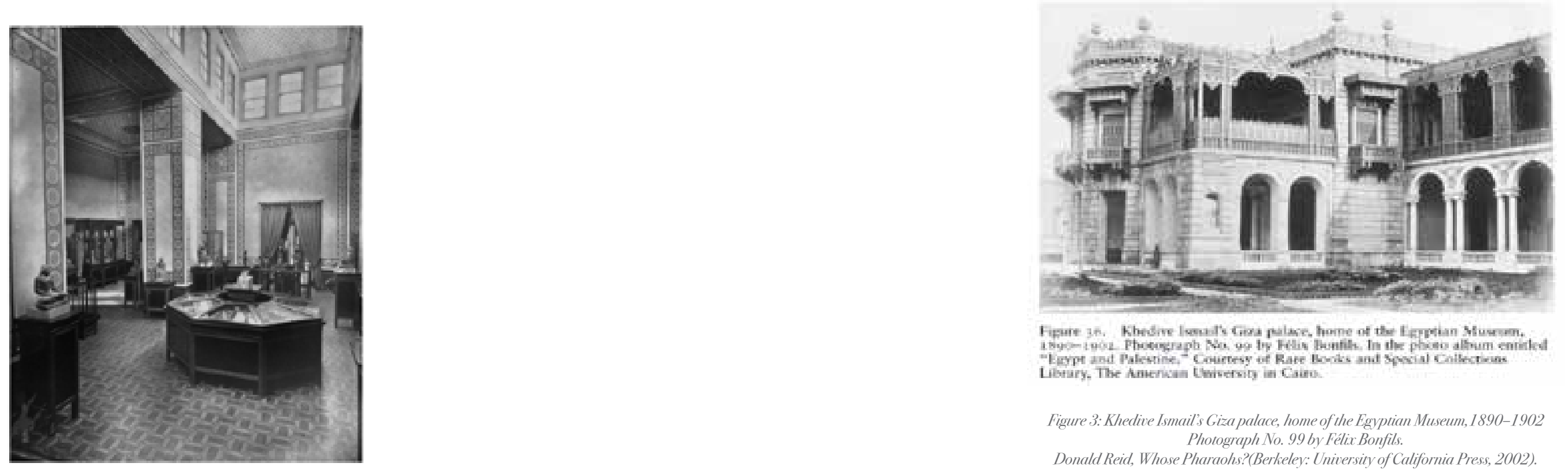

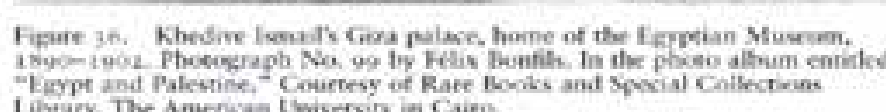

Figure 3: Khedive Ismail's Gizapalace, home of the Egyptian
Photograph No. 99 by Fellix Bonffil

No. 9 by rela sonfits.

Figure 1: Salle du centre (nefforincipale) at he Boulaq Musseum in Cairo, 1872 [Délié and Béchard

$10(2008) \cdot 1-37$
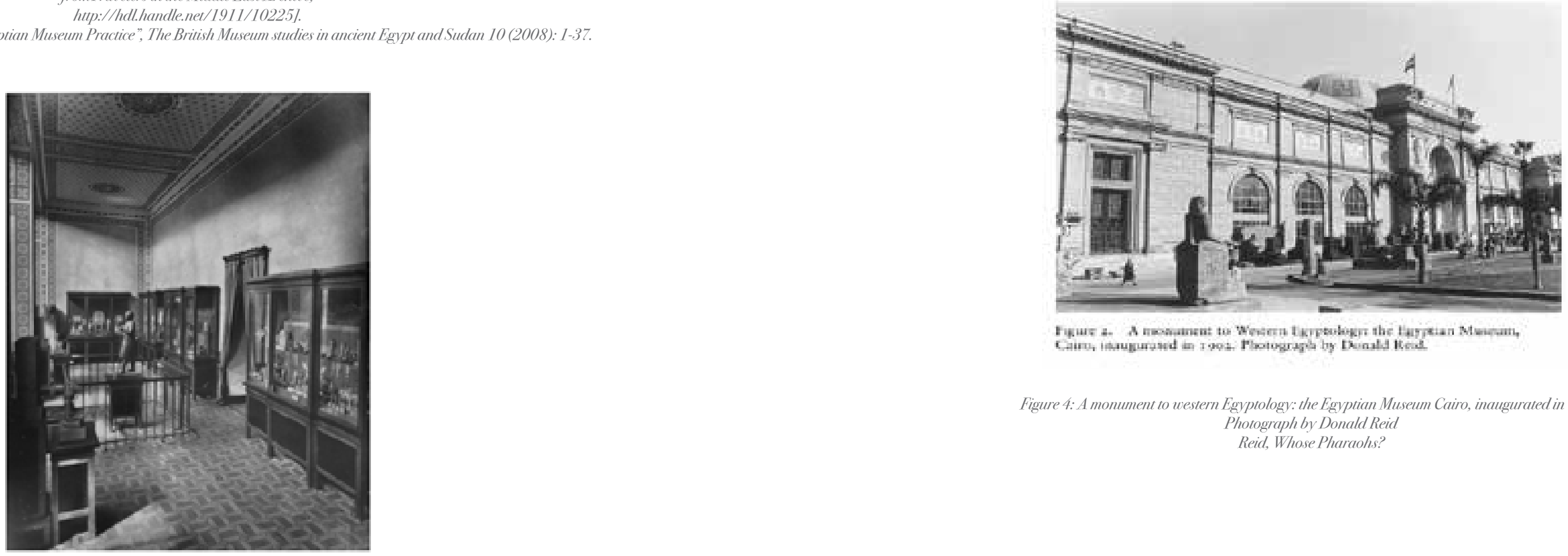

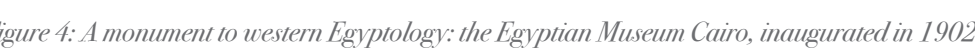
Photograph hy Donald Red

Figure 2: Salle du centre (neffaterale) at the Boulaq Museum in Cairo, 1872 [Délié and Béchard

hiomTraveleers in the Middle East Archites

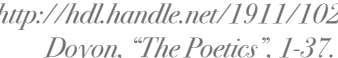



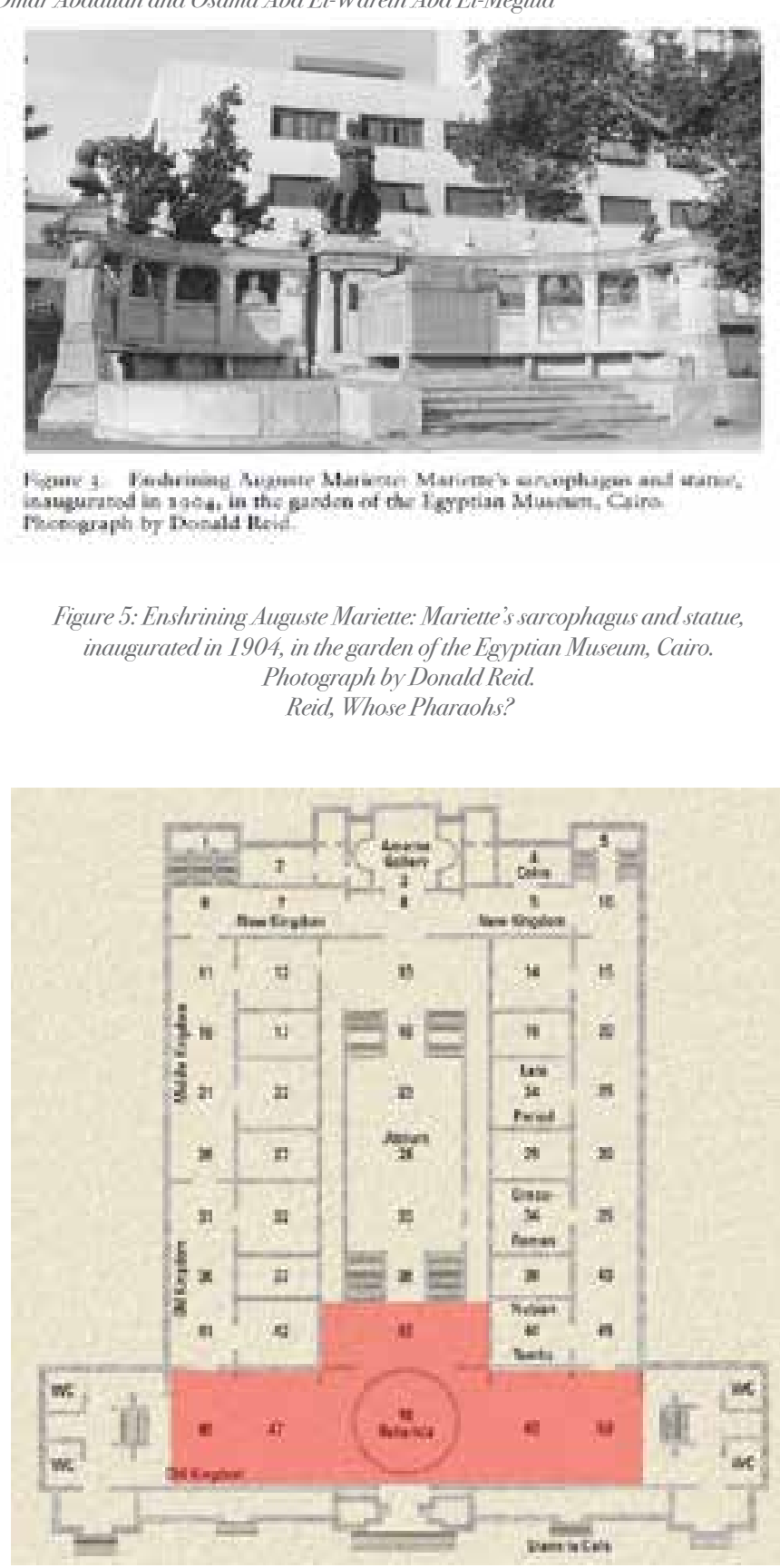

Figure 6: Groundfloor of the EMC:
Galleries highthighted in red will beredisplayed in work packlage
EU project work plan, short version (January, 2019)

\section{Bibliography:}

- Abou-Ghazi, Diaa. “The Egyptian museum”. Annales du Service des Antiquites de L’Egypte, Vol. LXVI (1978): 201 230

- Doyon, Wendy. “The Poetics of Egyptian Museum Practice”. The British Museum studies in ancient Egypt and Sudan, 10 (2008): $1-37$.

- Camacho, Kenaya N. "(Re) birth And Resurrection - Digitizing Antiquity: Preparing Ancient Egyptian Collection for the Digital World at The Grand Egyptian Museum and The Egyptian Museum in Cairo". Accessed in January 21, (2017). https://jscholarship.library.jhu.edu/bitstream/handle/1774.2/59081/Camacho\%2C\%20Kenaya\%20N.

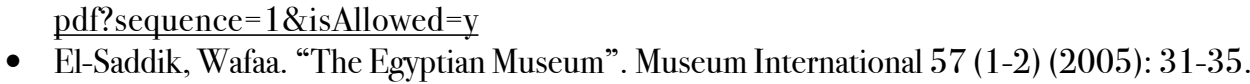

- EU project work plan, short version (January, 2019).

- Hawass, Zahi. "Antiquities and Secrets of the Egyptian Museum: A Century of Time". Issues and opinions, December 7, (2002): https://web.archive.org/web/20040109165300/http://www.ahram.org.eg:80/archive/2002/12/7/ OPIN12.HTM

- Hawass, Zahi. “A New Era for Museums in Egypt”. Museum International 57(1-2) (2005): 7-23.

Kamrin, Janice. "The Egyptian Museum Database, Digitizing, and Registrar Training Projects": Update 2012. Accessed

January 21, (2021). file:///Users/nagwaarafa/Downloads/The_Egyptian_Museum_Database_Digitizing\%20(1).pd Ministry of Tourism and Antiquities. “The Egyptian Museum”. Accessed January 21, (2021), https:// egymonuments.gov eg/en/museums/egyptian-museum.

Archaeology, Museums, and Eoyptian National Identity from Napoleon to World War I. Berkeley (2002).

- The Centennial of the EMC.Personal communication, August, (2020).

- Salahe-Din, Elham.The Museum Education Department; the EMC. Personal communication. April (2020).

- Sale, Mohamed and Sourouzian, Hourig. Official Catalogue of the Egyptian Museum, Cairo. The Organization of Egyptian Antiquies. Egypt(1987).

Museum Renovations. Personal Communication, November, (2020).

al-Damātī, Mamdūh. Wathā’iq al-mathaf al-mișrīi. Cairo : al-Majlis al-A 'lá lil-Āthār, Wizārat al-Thaqāfah, 2002. 